$\begin{gathered}\text { EPiC Series in Education Science } \\ \text { Volume 1, 2017, Pages 466-475 }\end{gathered}$
$\begin{gathered}\text { AUBEA 2017: Australasian Universities Build- } \\ \text { ing Education Association Conference 2017 }\end{gathered}$

\title{
The Impact of Individual Beliefs and Expectations on BIM Adoption in the AEC Industry
}

\author{
Shadi Batarseh ${ }^{* \dagger}$ and Imriyas Kamardeen ${ }^{1}$ \\ University of New South Wales, Sydney, Australia \\ shadibeunsw.edu.au, imriyascunsw.edu.au
}

\begin{abstract}
The use of Building Information Modelling (BIM) in the construction industry has been growing steadily during the last decade, yet there is a continues resistance to its adoption, due to some users' unawareness of BIM benefits. BIM adoption is associated with an individual's willingness towards using it which is driven by individual beliefs and expectations of BIM use consequences. Technology Acceptance Model (TAM) identified perceived usefulness (PE) and perceived ease of use PEOU as variables to inform us with user's mind-set and intentions towards the use of technology. This research proposes a conceptual framework for exploring and measuring individual willingness level for adopting BIM, based on individual beliefs and expectations of BIM use consequences in construction industry. The research conducted literature review on technology acceptance and use theories from IS mainstream to identify the individual beliefs and expectations variables, then conducted a literature review on case studies researches that directly applied TAM, to contextualize the variables into BIM in construction environment. The research outcome identified the individual willingness constructs to accept and use BIM: performance expectancy, effort expectancy, social conditions, facilitating conditions, and attitude towards using.
\end{abstract}

Keywords: Building Information Modelling, BIM adoption, individual believes and expectations, Technology Acceptance Model, user satisfaction.

\footnotetext{
* Masterminded EasyChair and created the first stable version of this document

${ }^{\dagger}$ Created the first draft of this document
} 


\section{Introduction}

Building Information Modelling (BIM) has been promoted as the ultimate solution for the coordination problems, mainly because it is considered as the central repository for information, and covers the entire cycle of the project from its conception up through demolition (Howard et al. 2017). Though it is agreed between researchers and practitioners that BIM has many potential benefits it is still unclear why BIM is not adopted, accepted and used significantly in the construction industry (Lee et al. 2013).

Studies in dig ital construction showed that resistance (Davis \& Songer 2008; Brewer \& Gajendran 2012) and other socio-techno behaviours may raise during early stages of adoption: e.g. stubbornness of employees about keeping the old CAD ways of working alive (Morlhon et al. 2014; Tu lenheimo 2015). The resistance happens because of even user's unawareness or un-satisfaction of BIM benefits and advantages (Arayici et al. 2011Brewer \& Gajendran 2012; Lee et al. 2013)

The acceptance to adopt BIM technology is not a simple case of approval or rejection, various researchers have proposed diverse factors that can influence technology adoption and acceptance. For instance, Davies \& Harty (2013) identified that the individual beliefs and expectations regarding the technology consequence use have important role in successful adoption. Deutsch et al. (2011) discussed three change drivers due to technology adoption as people, business, and the technology itself. Furthermore, Venkatesh et al. (2003) attested that performance expectancy, effort expectancy, social influence and facilitating conditions determine the rate of technology acceptance which are subject to people's attitudes towards technology use. In addition, the technology acceptance model proposed that the individual's behavioural intention to use new technology is determine by two beliefs which are perceived usefulness and ease of use. Also, Jacobsson \& Linderoth (2012) confirmed that occupational skills and nature of work task influence ICT technology adoption. Based on these facts, there is an indication that the acceptance of BIM technology in the Architectural Engineering and Construction (AEC) industry can possibly be influenced by individual prerequisites. Therefore, this study aims to explore the influence and impact of individual beliefs and expectations on individual's willingness to adopt BIM and thereby true implementation in the industry.

\section{Literature Review}

Literature review was conducted in two broad areas; theories of technology adoption and BIM adoption in construction. The former informed the factors critical to the adoption of any technology whist the latter investigated how these theories apply in the context of BIM adoption in the construction industry. Among the technologies adoption theories reviewed, two heavily applied ones are discussed below, namely: Technology Acceptance Model (TAM) and Unified Theory of Acceptance and Use of Technology (UTAUT).

\subsection{Technology Acceptance Model (TAM)}

Technology Acceptance Model (TAM) was introduced by Davis (1989). TAM is an adoption of Theory of Reasoned Action (TRA) and Theory of Planned Behaviour (TPB), specifically tailored for user acceptance of Information Systems (IS). The purpose of TAM is to explain individuals' acceptance of new technologies and their related behaviours. In TAM, Perceived Usefulness (PU) and Perceived Ease of Use (PEOU) are the key constructs of IS acceptance behaviour. As shown in Figure 1, TAM proposes external variables that directly affect PU and PEOU, which consequently affect indirectly the attitude towards the use (ATT) of a technology, and ultimately leads to the actual use of the technology by influencing PU and PEOU. 
TAM proposes that the individual's behavioural intention to use a new technology is determined by two beliefs: perceived usefulness, defined as the extent to which a person believes that using the system will enhance his or her job performance; and perceived ease of use, defined as the extent to which a pers on believes that using the system will be free of effort. TAM assumes that the effects of external variables on intention to use are mediated by perceived usefulness and perceived ease of use.

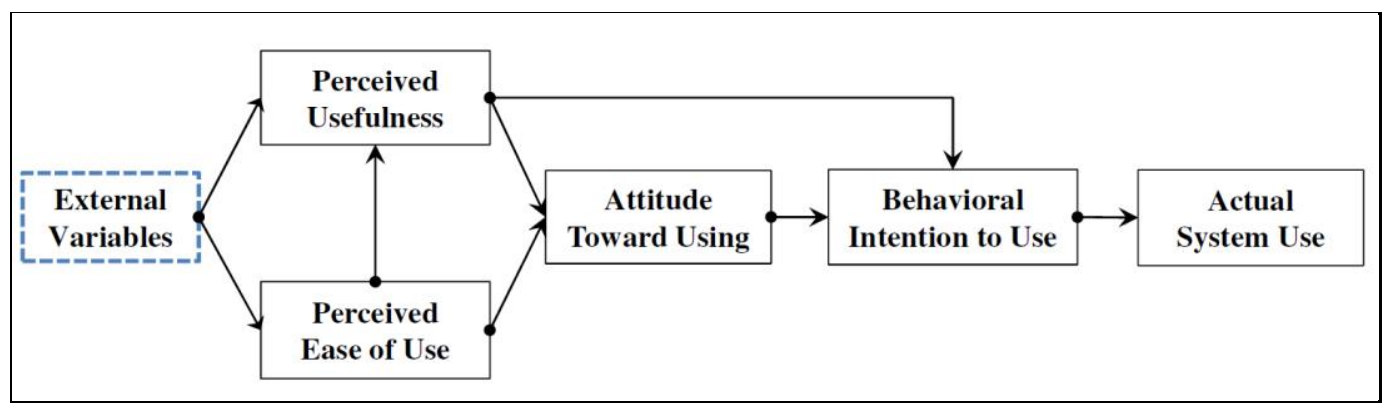

Figure 1: Technology Acceptance Model, (Source: Davis 1989)

Venkatesh and Davis (2000) extended TAM into TAM2 by adding subjective norms as an additional predictor of the behavioural intention, in addition to concluding the definition of external variables (see Figure 2). Further research on TAM led to the development of TAM3 by Venkatesh \& Bala (2008)

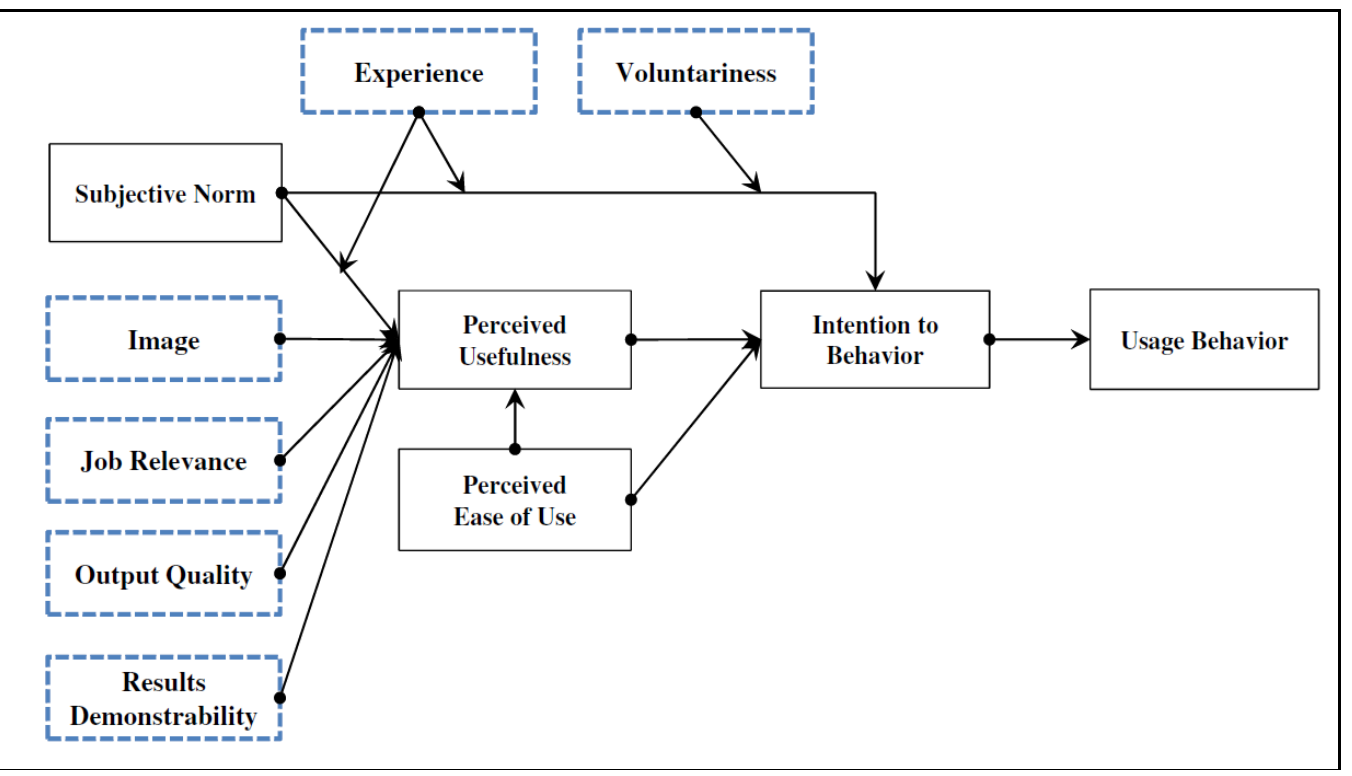

Figure 2: Technology Acceptance Model 2, (Source: Venkatesh \& Davis 2000) 


\subsection{Unified Theory of Acceptance and Use of Technology (UTAUT)}

Venkatesh et al. (2003) proposed the Unified Theory of Acceptance and Use of Technology (UTAUT) based on eight technology acceptance and behavior-related theories: Technology Acceptance Model (TAM/TAM2) (Davis 1989), Theory of Reasoned Action (TRA) (Fishbein \& Ajzen 1975), Motivation Model (MM) (Davis et al. 1992), Theory of Planned Behaviour (TPB) (Ajzen 1991), Model of Personal Computing Utilization (MPCU) (Thompson et al. 1991), Innovation Diffusion Theory (IDT) (Moore \& Benbasat 1991), and Social Cognitive Theory (SCT) (Co mpeau et al. 1999).

Venkatesh et al. (2003) proposed and defined four constructs of UTAUT (see Figure 3): (1) Performance Expectancy (also referred as Perceived Usefulness); the degree to which an individual believes that using the technology will help him or her to achieve improvements in job performance, (2) Effort Expectancy (also referred as Perceived Ease of Use); the degree of ease linked with the use of the technology, (3) Social Influence (also referred as subjective Norms); the degree to which an individual perceives that others believe he or she should use the new technology, and (4) Facilitating Conditions, the degree to which an individual believes that an organizational and technical infrastructure exists to support the use of the technology.

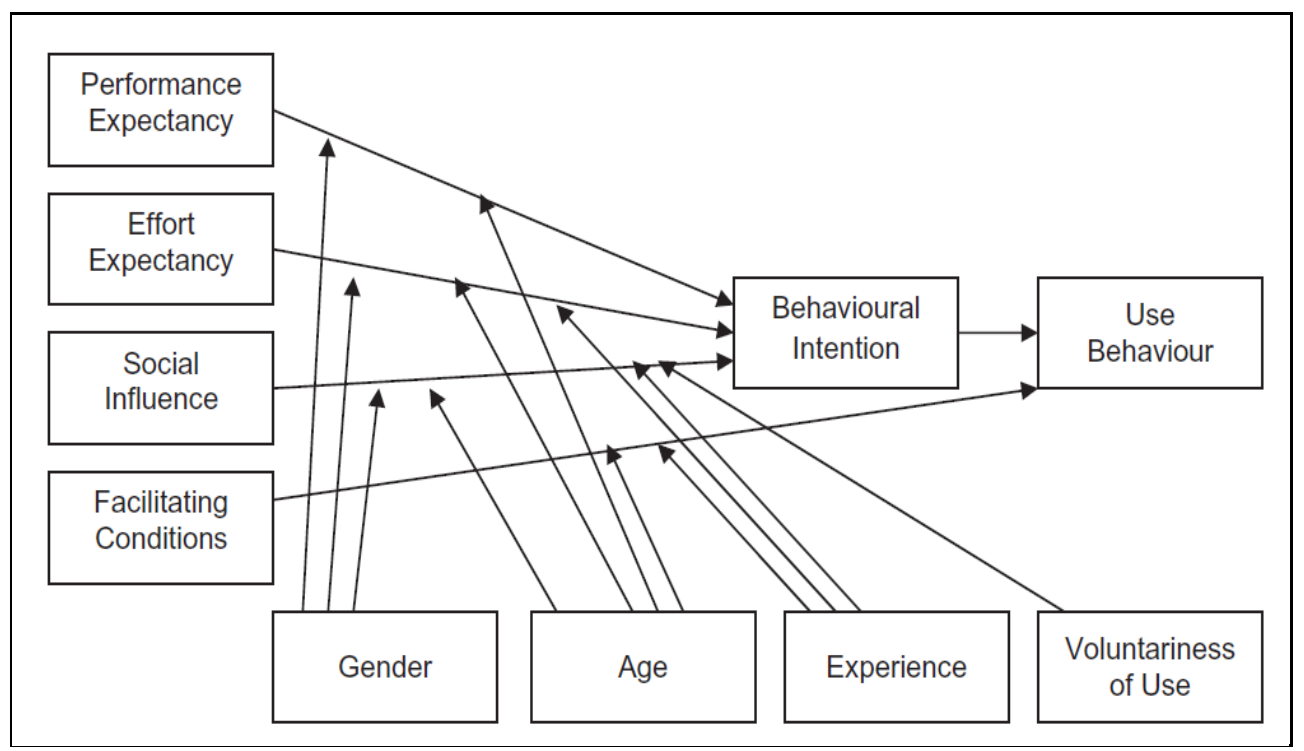

Figure 3: Unified Theory of Acceptance and Use of Technology, (Source: Venkatesh et al. 2003)

\subsection{BIM Acceptance in the Construction Industry}

The above theories have been applied by few researchers to investigate BIM adoption in the construction industry, which are discussed below.

In the South Korean construction industry context, a BIM Acceptance Model (BAM) was proposed by Lee et al. (2013b). BAM identified $28 \mathrm{key}$ factors and used them as TAMs external variables. The factors were classified into; compatibility, output quality, collective efficiency, 
organizational innovativeness, self-efficacy, personal innovativeness, top management support, internal pressure, and external pressure. The research concluded that perceived usefulness has a significant impact on individual intent to accept BIM, also concluded that organizational co mpetency has the most significant impact on perceived ease of use.

Davies and Harty (2013a) explored the individual beliefs about BIM consequence use in large construction contracting organizations in the United Kingdom. The examined the relationship between the salient individual-level variables; performance, effort, social influence, facilitating conditions, compatibility, and attitude towards using the technology. The outcome showed that there is a strong relationship between the expectations that BIM would enhance job performance (user's perception) and the expectation that BIM use was compatible with preferred and existing ways of working (facilitating conditions).

Wang and Song (2017)examined the influence of five variables on BIM user satisfaction in the AEC industry. Three of these variables were from TAM, which are perceived benefits, perceived ease of use, and attitude, in addition to two management variables: top management support, and manage ment by objective. The results showed that perceived usefulnes s, top manage ment support and management by objective are significantly as sociated with BIM user satisfaction, and the influence of management by objective on BIM user satisfaction is stronger than top management support and perceived usefulness. Also, perceived ease of use and attitude have a significant influence on perceived usefulness.

Howard et al. (2017) directly used UTAUT to explore the individual perceptions towards working with BIM in the UK AEC industry. The study extended UTAUT with extra variables: gender, age, and experience. The results revealed that performance expectancy does not directly affect the behavioural intention, suggesting that BIM is perceived as an unrewarded addition to existing work processes. The research finding highlights the need to redefine the strategies, policies, and incentive schemes to advance the acceptance of BIM in the UK.

Merschbrock \& Nordahl-Rolfsen (2016) directly used TAM to examine ironworkers' acceptance of using BIM for facilitating on-site placement of reinforcement bars with a sophisticated virtual model, replacing the traditional way of using shop-drawings for fabrication and placement of the reinforcement bars, for the Oslo new airport terminal project in Norway. The findings showed that the workers perceived the virtual model as more beneficial over the paper-based shop drawings.

The above mentioned researches explored the influence of users' perception on BIM acceptance, and the effect of external variables, such as; top management role, gender, age, experience, beliefs and expectations, efficiency compatibility, output quality, collective efficiency, organizational innovativeness, self-efficacy, and personal innovativeness. Moreover, both user satisfaction and perceived usefulness emphasise on the individuals' perception of the new technology; their beliefs and expectations on how the new technology will affect their work in addition to an embedded assumption that their positive expectations about using BIM will result in benefits (positive impact) for the organization. Aligning users' perception with their expectations and believes for the technology adoption will reveal the satisfaction level. These factors are significant for understanding BIM acceptance and use (Davies \& Harty 2013).

Information System stream identified the three phases for innovation adoption in business: preadoption phase, actual adoption phase, and post-adoption phase. The above mentioned researches mainly discuss the user's acceptance for BIM in actual adoption phase. The proposed willingness framework will be checking the user's mindsets in pre-adoption phase to predict users' reactions and behaviors before adoption, which is considered the research knowledge gap.

Performing "willingness health-check" for employee's readiness for BIM adoption, will be valuable for organizational management in decision making and planning proper strategies for enhancing BIM adoption. 


\section{Framework of BIM Adoption Willingness and Behaviour}

Figure 4 illustrates a new framework that is developed to address the knowledge gap identified above. The framework draws on technology acceptance and use theories mentioned in the literature review to measure the individual willingness level of using BIM, and consequently the reflected actual usage behaviour. Measuring the willingness level will reveal the behavioural intention whether it was resistance (negative level) or motivation (positive level). Understanding the variables that affect the level of willingness e will assist in controlling BIM adoption behaviours.

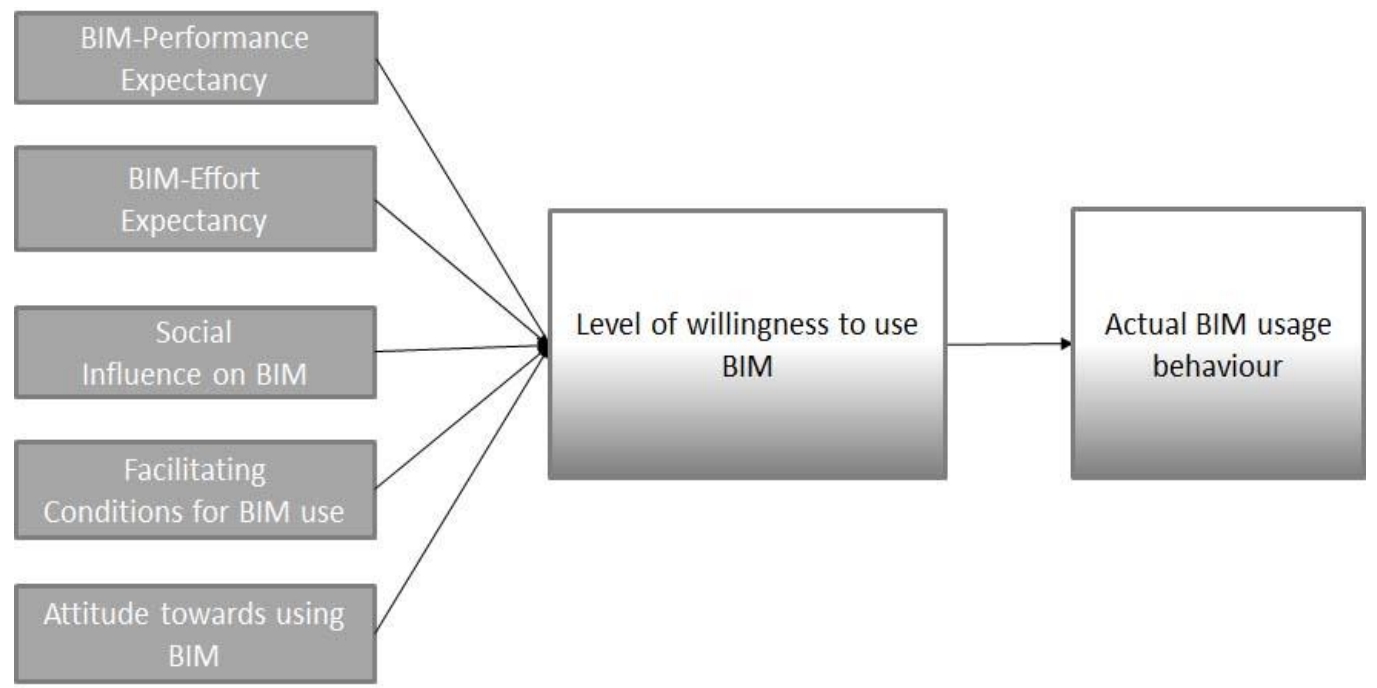

Figure 4: Research conceptual framework

The IS literature clarified how perceived usefulness PU and perceived ease of us PEOU form the individual perception of technology use, and consequently the individual expectations for performance expectation PE and effort expectation EE. UTAUT identified social influence SI and facilitating condition FC as influential variables for individual beliefs for the technology consequence use. See Table 1 for UTAUT constructs referenced to their original technology acceptance and theories. 


\begin{tabular}{|c|c|c|}
\hline $\begin{array}{l}\text { UTAUT } \\
\text { constructs }\end{array}$ & Corresponding theory title & $\begin{array}{l}\text { Corresponding technology acceptance } \\
\text { theory }\end{array}$ \\
\hline $\begin{array}{l}\text { Performance } \\
\text { Expectancy }\end{array}$ & Perceived Usefulness & $\begin{array}{l}\text { Technology Acceptance Model (Davis } \\
\text { 1989) }\end{array}$ \\
\hline Effort Expectancy & Perceived Ease of Use & $\begin{array}{l}\text { Technology Acceptance Model (Davis } \\
\text { 1989) }\end{array}$ \\
\hline Social Influence & Social Factors & $\begin{array}{l}\text { Model of Personal Computing } \\
\text { Utilization (Thompson et al. 1991) }\end{array}$ \\
\hline $\begin{array}{l}\text { Facilitating } \\
\text { Condition }\end{array}$ & Facilitating Conditions & $\begin{array}{l}\text { Model of Personal Computing } \\
\text { Utilization (Thomps on et al. 1991) }\end{array}$ \\
\hline $\begin{array}{l}\text { Facilitating } \\
\text { Condition }\end{array}$ & Compatibility & $\begin{array}{l}\text { Innovation Diffusion Theory (Moore \& } \\
\text { Benbasat 1991) }\end{array}$ \\
\hline $\begin{array}{l}\text { Attitude Toward } \\
\text { using Technology }\end{array}$ & Attitude Toward Behaviour & $\begin{array}{l}\text { Technology Acceptance Model (Davis } \\
\text { 1989) }\end{array}$ \\
\hline
\end{tabular}

Table 1: UTAUT Constructs

The conceptual framework contextualises the UTAUT constructs and their item wording to BIM. The conceptual frame work postulates that the degree of actual BIM use in one's job role is dictated by his/her level of willingness to adopt BIM, which in turn is influenced by five factors, such as: (1) BIM performance expectance (BPE), (2) BIM effort expectance (BEE), (3) social influence on BIM (SIB), (4) facilitating condition for BIM use (FCB), and (5) attitude towards using BIM (ATTB). Table 2 below shows the contextualised variables definitions and the item wording originated from the original theories. The last column of the table lists questions that can help to measure each of the construct with construction profes sionals. 


\begin{tabular}{|c|c|c|}
\hline Variable & Scale Description & Scale item wording \\
\hline $\begin{array}{l}\text { BIM- } \\
\text { Performance } \\
\text { Expectancy }\end{array}$ & $\begin{array}{l}\text { The degree to which a } \\
\text { person believes that } \\
\text { using a particular system } \\
\text { would enhance his or her } \\
\text { job performance (Davis } \\
\text { 1989). }\end{array}$ & $\begin{array}{l}\text { 1. Using BIM in my job would enable me to } \\
\text { accomplish tasks more quickly. } \\
\text { 2. Using BIM would improve my job } \\
\text { performance. } \\
\text { 3. Using BIM in my job would increase my } \\
\text { productivity. } \\
\text { 4. Using BIM would enhance my effectiveness } \\
\text { on the job. } \\
\text { 5. Using BIM would make it easier to do my } \\
\text { job. } \\
6 \text {. I would find the system useful in my job. }\end{array}$ \\
\hline $\begin{array}{l}\text { BIM-Effort } \\
\text { Expectancy }\end{array}$ & $\begin{array}{l}\text { The degree to which a } \\
\text { pers on believes that } \\
\text { using a system would be } \\
\text { free of effort (Davis } \\
\text { 1989). }\end{array}$ & $\begin{array}{l}\text { 1. Learning to operate BIM would be easy for } \\
\text { me. } \\
\text { 2. I would find it easy to get BIM to do what I } \\
\text { want it to do. } \\
\text { 3. My interaction with BIM would be clear and } \\
\text { understandable. } \\
\text { 4. I would find BIM to be flexible to interact } \\
\text { with. } \\
\text { 5. It would be easy for me to become skilful at } \\
\text { using BIM. } \\
\text { 6. I would find BIM easy to use. }\end{array}$ \\
\hline $\begin{array}{l}\text { Social } \\
\text { Influence on } \\
\text { BIM }\end{array}$ & $\begin{array}{l}\text { The individual's } \\
\text { internalization of the } \\
\text { reference group's } \\
\text { subjective culture. and } \\
\text { specific interpers onal } \\
\text { agreements that the } \\
\text { individual has made with } \\
\text { others, in specific social } \\
\text { situations (Thompson et } \\
\text { al. 1991). }\end{array}$ & $\begin{array}{l}\text { 1. I use BIM because of the proportion of co- } \\
\text { workers who use the system. } \\
\text { 2. The senior management of this business has } \\
\text { been helpful in the use of BIM. } \\
\text { 3. My supervis or is very supportive of the use of } \\
\text { BIM for my job. } \\
\text { 4. In general, the organization has supported the } \\
\text { use of BIM. }\end{array}$ \\
\hline $\begin{array}{l}\text { Facilitating } \\
\text { Condition for } \\
\text { BIM use }\end{array}$ & $\begin{array}{l}\text { Objective factors in the } \\
\text { environment that } \\
\text { observers agree make an } \\
\text { act easy to do. including } \\
\text { the provision of } \\
\text { computer support } \\
\text { (Thompson et al. 1991). } \\
\text { The degree to which an } \\
\text { innovation is perceived } \\
\text { as being consistent with } \\
\text { existing values, needs. } \\
\text { and experiences of } \\
\text { potential adopters } \\
\text { (Moore \& Benbasat } \\
\text { 1991). }\end{array}$ & $\begin{array}{l}\text { 1. Guidance was available to me in the selection } \\
\text { of BIM. } \\
\text { 2. Specialized instruction concerning BIM was } \\
\text { available to me. } \\
\text { 3. A specific person (or group) is available for } \\
\text { assistance with BIM difficulties. } \\
\text { 4. Using BIM is compatible with all aspects of } \\
\text { my work. } \\
\text { 5. I think that using BIM fits well with the way I } \\
\text { like to work. } \\
\text { 6. Using BIM fits into my work style. }\end{array}$ \\
\hline
\end{tabular}




$\begin{array}{ll}\text { Attitude } & \text { An individual's positive } \\ \text { Toward using } & \text { or negative feelings } \\ \text { BIM } & \begin{array}{l}\text { about performing the } \\ \text { target behaviour(Davis } \\ \text { 1989). }\end{array}\end{array}$

Attitude An individual's positive

1. I have control over using BIM.

2. I have the resources necessary to use BIM.

3. I have the knowledge neces sary to use BIM.

4. Given the resources, opportunities and knowledge it takes to use BIM, it would be easy for me to use BIM.

5. BIM is not compatible with other systems I

Table 2: Constructs description and item wording

\section{CONCLUSION}

This research proposed a conceptual framework for measuring the level of willingness for using BIM, based on individual beliefs and expectations variables: performance expectance, effort expectance, social influence, facilitating condition, and attitude toward using BIM. Accordingly, willingness level will be reflected on the actual BIM usage behaviour whether it is motivated or resistance behaviour.

To verify the conceptual frame work, a questionnaire will be created based on the item desertion shown in Table 2 above, and will be sent to BIM users in Australian construction organizations.

Understanding employees' behaviours based on willingness level will be valuable and beneficial for organizational management for different purposes: assist management in putting implementation strategies, reduce the implementation cost and financial risk, will guide in setting BIM benefit realisation context for users, and finally it will help management to work on their motivation schemes or incentives.

\section{REFERENCES}

Ajzen, I., 1991. The theory of planned behavior. Orgnizational Behavior and Human Decision Processes, 50, pp.179-211.

Arayici, Y. et al., 2011. BIM adoption and implementation for architectural practices. Structural Survey, 29(1), pp.7-25. Available at: http://usir.salford.ac.uk/13046/1/BIM_Adoption_and_Implementation_for_Architectural_Practices_P ublished_version.docx\%5Cnhttp://search.proquest.com/docview/859629660?accountid=10297\%5Cnh ttp://sfx.cranfield.ac.uk/cranfield?url_ver=Z39.88-2004\&rft_val_fmt=in.

Brewer, G. \& Gajendran, T., 2012. Attitudes, behaviours and the transmission of cultural traits: Impacts on ICT/BIM use in a project team. Construction Innovation: Information, Process, Management, 12(2), pp.198-215. Available at: http://www.scopus.com/inward/record.url?eid=2-s 2.084859860089\&partnerID=tZOt x3y 1 .

Compeau, D., Higgins, C.A. \& Huff, S., 1999. Social cognitive theory and individual reactions to computing technology: A longitudinal study. MIS Quarterly, 23(2), pp.145-158. Available at: http://search.ebscohost.com/login.aspx?direct=true $\& d b=c p h \& A N=2083384 \&$ site=ehost - live.

Davies, R. \& Harty, C., 2013. Measurement and exploration of individual beliefs about the consequences of building information modelling use. Construction Management and Economics, 31(March 2015), pp.1110-1127. Available at: http://www.tandfonline.com/doi/abs/10.1080/01446193.2013.848994.

Davis, F., 1989. Perceived Usefulness, Perceived Ease Of Use, And User Accep. Computer and information systems. 
Davis, F.D., Bagozzi, R.P. \& Warshaw, P.R., 1992. Extrinsic and Intrinsic Motivation to Use Computers in the Workplace. Journal of Applied Social Psychology, 22(14), pp.1111-1132.

Davis, K.A. \& Songer, A.D., 2008. Resistance to it change in the AEC ind ustry: An individual assessment tool. Electronic Journal of Information Technology in Construction, 13, pp.56-68.

Howard, R., Restrepo, L. \& Chang, C.-Y., 2017. Addressing individual perceptions: An application of the unified theory of acceptance and use of technology to building information modelling. International Journal of Project Management, 35(2), pp.107-120. Available at: http://dx.doi.org/10.1016/j.ijproman.2016.10.012.

Jacobsson, M.\& Linderoth, H.C.J., 2012. User perceptions of ICT impacts in Swed ish construction companies : "it" $\mathrm{s}$ fine , just as it is 'User perceptions of ICT impacts in Swedish construction companies : " it" s fine , just as it is '., (November), pp.37-41.

Lee, S., Yu, J. \& Jeong, D., 2013. BIM Acceptance Model in Construction Organizations. Journal of Management in Engineering, 31(1988), p.4014048. Available at: http://ascelibrary.org/doi/abs/10.1061/(ASCE)ME.1943-5479.0000252.

Merschbrock, C. \& Nordahl-Rolfsen, C., 2016. BIM technology acceptance among reinforcement workers - The case of os lo airport's terminal 2. Journal of Information Technology in Construction, 21(March), pp.1-12.

Moore, G.C. \& Benbasat, I., 1991. Development of an instrument to measure the perceptions of adopting an information technology innovation. Information Systems Research, 2(3), pp.192-222.

Morlhon, R., Pellerin, R. \& Bourgault, M., 2014. Building Information Modeling Implementation through Maturity Evaluation and Critical Success Factors Management. Procedia Technology, 16, pp.1126-1134. Available at: http://dx.doi.org/10.1016/j.protcy.2014.10.127.

Randy Deutsch, AIA \& AP, L., 2011. BIM And Integrated Design-Strategies For Architectural Practice, Available at: http://www.aia.org/practicing/akr/AIAB090847.

Thompson, R.L., Higgins, C.A. \& Howell, J.M., 1991. Personal computing: Toward a conceptual model of utilization. MIS Quarterly, 15(1), pp.124-143.

Tulenheimo, R., 2015. Challenges of implementing new technologies in the world of BIM - Case study from construction engineering industry in Finland. Procedia Economics and Finance,

21(Henttinen 2012), pp.469-477. Available at: www.sciencedirect.com.

Venkatesh, V. et al., 2003. User Acceptance of Information Technology: Toward a Unified. MIS Quarterly, 27(3), pp.425-478.

Venkatesh, V. \& Bala, H., 2008. Technology Acceptance Model 3 and a Research Agenda on Interventions. Decision Sciences, 39(2), pp.273-315. Available at: http://doi.wiley.com/10.1111/j.1540-5915.2008.00192.x.

Venkatesh, V. \& Davis, F., 2000. A theoretical extension of the Technology Acceptance Model: Four longitudinal field studies. Management Science, 46(2), pp.186-204. Available at: http://web.b.ebscohost.com.ezproxy.ntu.ac.uk/ehost/pdfviewer/pdfviewer?sid=7efbe098-d47d-49f19e6d-f8f7f3f49870@ses sionmgr198\&vid=2\&hid=121.

Wang, G. \& Song, J., 2017. The relation of perceived benefits and organizational supports to user satisfaction with building information model (BIM). Computers in Human Behavior, 68, pp.493-500. Available at: http://linkinghub.els evier.com/retrieve/pii/S0747563216308226. 